\title{
The Experimental Research on the Influence of Materialism and the Emotion of Awe on Life Satisfaction and Products Preference
}

\author{
Ye Tian1, Dong Lu ${ }^{2 *}$ \\ ${ }^{1}$ School of Economics and Management, Southwest Jiaotong University, Chengdu, China \\ ${ }^{2}$ School of Business, Sichuan Normal University, Chengdu, China \\ Email: ye.tian@my.swjtu.edu.cn, dlu@sicnu.edu.cn
}

Received 10 September 2015; accepted 23 October 2015; published 27 October 2015

Copyright (C) 2015 by authors and Scientific Research Publishing Inc.

This work is licensed under the Creative Commons Attribution International License (CC BY).

http://creativecommons.org/licenses/by/4.0/

c) (i) Open Access

\begin{abstract}
The materialism plays a negative role in people's life that if people have high materialism, normally they would show low life satisfaction and excessively pursue the material world but neglect the spiritual world. However, the emotion of awe, as a typical kind of positive emotions, can help people to raise their satisfaction in life and also promote people to approach the spiritual world. In this study, we used an experiment to investigate how the emotion of awe can offset against the negative impact from materialism on people. The results of the experiment indicated that if people experienced the awe emotion, no matter how high their materialism level were, they would increase their life satisfaction. And the people with high materialism would turn to prefer to the experience-based products when they acquired the emotion of awe.
\end{abstract}

\section{Keywords}

Materialism, Awe, Life Satisfaction, Products Preference

\section{Introduction}

The cultural studies scholar Tao argued that since the 1990s the materialistic craze had been a wave raised in the Chinese mainland [1]. Under the sweeping of the materialistic craze wave, people generally show the alienation and apathy to the public world. And people also decline the enthusiasm and are cooling down the involvement to the political and social activities. By contrast, people’s material desires, unlimited pursuit of physical pleasure

${ }^{*}$ Corresponding author.

How to cite this paper: Tian, Y. and Lu, D. (2015) The Experimental Research on the Influence of Materialism and the Emotion of Awe on Life Satisfaction and Products Preference. Open Journal of Social Sciences, 3, 138-145.

http://dx.doi.org/10.4236/jss.2015.310020 
and fascination bring lots of harm to the society that people decline the interpersonal and public performance, and concern secular substance more than spiritual world. The psychologist Myers have pointed out people's behavior in social activities cannot be separated from the driving performance of mental activity, and the emotion always plays an important role in people's mental activity [2]. And the research on positive emotions makes a further explanation about how positive emotions do help people to promote and build the positive behaviors. One of the most representative theories on positive emotions is from Fredrickson's The Broaden-and-build Theory of Positive Emotions [3], which suggests that positive emotions can not only expand the scope of people's awareness, but also help to build people's individual resources. Specifically, on the one hand, the positive emotions encourage people to produce more thinking, broaden the scope of attention, enhance cognitive flexibility, and also expand the individual's cognitive map; on the other hand, the positive emotions help people to build their internal resources and other resources between individuals, improve their psychological and physiological resilience as well as enhance their social connection, and promote people to actively respond to the social activities, strive to create opportunities for more extensive social resources. Thus, when people cultivate the positive emotions, they cannot only be offset to the adverse affection which the secular materialism brings, but also have a new understanding of the life satisfaction, and change the preference to make decisions when considering the pursuit of goods between material and spiritual (experiential) products. Shiota et al. also indicated that the emotion of awe [4], as one of the typical positive emotions, can exaggeratingly facilitate people to be happier and more satisfactory, and also promote people to have more positive behaviors. So the interest of this study is to find out whether the positive role of awe emotion can make affirmative interventions for the negative effects of materialism.

\subsection{The Materialism}

Previous scholars have different definitions on the materialism. Richins and Dawson consider that the materialism is a personal materialistic value, which stresses the importance of personal material wealth [5]. Sirgy considers that the materialism is a kind of living conditions, which emphasizes the material things in life have more importance compared to other things in life [6]. Chan and Prendergast believe that the materialism is an attitude in life, which emphasizes the central stuffs in life mainly include happiness and success [7]. Overall, the materialism can be summarized as the situation that people are keen on the physical world but neglect the spiritual world. In another word, people are overwhelmingly strengthening the material desires, and are weakening the spiritual needs for their lifestyle, opinions, attitudes and tendencies. Richins and Dawson also point out the three core components constituting the materialism [5], including 1) the centrality, which refers to the substance of property becomes the center in the individual's life; 2) the happiness, which refers to material wealth is the main source to make up the individual's life satisfaction; 3) the success, which refers to the individual's belief that only wealth can be labeled as the evaluation of success. Based on the definition, Richins and Dawson designed the dimensions in the MVS (the Material Values Scale) to measure the individual's materialism.

\subsection{The Effect of the Materialism on Life Satisfaction and Product Preference}

Numerous studies in the past indicated that the materialism would have long-term negative impact on the individual's life and behaviors. For example, the materialism can not only lead to the individual's physical and mental illness [8], but also give rise to the negative impact on well-being, such as loneliness [9], depression [10], and low self-esteem [11]. Moreover, because the materialism would damage people's self-esteem and well-being, thus it further impedes people's satisfaction about their life [8]. So, due to the negative effect caused by the materialism, people would reduce their life satisfaction [12].

Previous studies also linked the materialism with consumer behavior research. For example, Dittmar found that the materialism may lead consumer have dysfunctional behavior [13], such as compulsive buying; and a lot of studies also found that the materialism can influence consumer's decision making, such as the product preference about experience-based products and materials-based products [14]. According to Richins and Dawson's study [5], people with high materialism are more likely to consume materials-based products, because the acquisition to the materialistic substance is extremely important to their self-images and the life satisfaction in their minds. In addition, when considering the preference between the materials-based products and experience-based products, the materialists would prefer to materials-based products which increase their pleasure and promote their enjoyment for life [15]. Howell et al.'s findings support the above conclusion as well [16]. They found the 
negative correlation between the individual's degree of materialism and the individual's behavior that preferring experience-based products.

\subsection{The Emotion of Awe and Its Moderating Effect}

The emotion of awe is one typical kind of positive emotions [4]. Keltner and Haidt used the prototype approach to give a definition that the emotion of awe is a strange feeling [17], including lots of complex emotional experience. When people are facing a number of broader, more ambitious things which get beyond their current understandings, they will receive such feeling. And the emotion of awe can make people to get the perceived vastness, as well as to get a need for accommodation through psychological schema changes. Shiota et al. also point out that, like other positive emotions, the emotion of awe is able to activate people's positive tendencies of action [4]. The previous empirical studies showed that the emotion of awe can promote people's positive behavior, and promote people for the pursuit of the spiritual world. For example, Rudd et al. found that when people experienced awe emotion, they would significantly feel their life satisfaction getting higher; not only that, Rudd et al. also found that in the merchandise selection test, if people were induced to have the emotion of awe, they would prefer the experience-based products over the materials-based products [18]. Similarly, van Cappellen and Saroglou found in the decision between two types of tourism destination [19], Tibet (spiritual type) and Haiti (hedonic type), if people were induced to experience the emotion of awe, most of them would prefer to choose Tibet as their travel destination rather than Haidi. And this test showed that in the condition with stimulus of awe emotion, people were thinking about the spiritual world more.

In a series of studies, Kasser and Ryan indicated that those people who expressed more strongly materialism would experience fewer positive emotions, as well as increase their depression, anxiety and abuse of substance [20]. Because the materialists have unrealistic expectations that they suppose the material type of merchandise can provide them a great deal of satisfaction [21]. Before purchasing, the materialists have a higher level of expectation to get the anticipatory positive emotion than the non-materialists [22]. However, such kind of the positive emotion is not real or is not expected to continuous that once if the material type of merchandise cannot get to meet those people's expectations or maintain their anticipatory positive emotion, they will reduce their actual positive emotions to produce dissatisfaction [23].

In general, Curtin pointed out that the positive emotion of awe can bring many benefits for people in the emotional, psychological and physiological aspects [24]. These benefits may not only be offset by the negative impact which people suffered in the materialistic environment, but also improve people's positive attitude towards life. And Keltner and Haidt's study also indicated that the emotion of awe possesses a kind of force to widely combine the social entities [17]. For example, the emotion of awe can make the individual to link with their state or human society. This combination conforms to Fredrickson's the Broaden-and-build Theory of Positive Emotions [3], namely, the emotion of awe helps people expand the purview of the personal cognitive range and construct the individual resources.

Therefore, this study presents the following hypotheses:

H1a: For the individual with high materialism, if experiences the emotion of awe, the individual would have a middle life satisfaction.

H1b: For the individual with high materialism, if experiences the emotion of peace, the individual would have a low life satisfaction.

H1c: For the individual with low materialism, if experiences the emotion of awe, the individual would have a high life satisfaction.

H1d: For the individual with low materialism, if experiences the emotion of peace, the individual would have a middle life satisfaction.

H2a: For the individual with high materialism, if experiences the emotion of awe, the individual would have no preference between the materials-based products and the experience-based products.

H2b: For the individual with high materialism, if experiences the emotion of peace, the individual would prefer to the materials-based products over the experience-based products.

H2c: For the individual with low materialism, if experiences the emotion of awe, the individual would prefer to the experience-based products over the materials-based products.

H2d: For the individual with low materialism, if experiences the emotion of peace, the individual would have no preference between the materials-based products and the experience-based products. 


\section{Research Methods}

\subsection{Experiment Design and Participants}

This study adopted the $2 \times 2$ analysis that all the participants were divided into four different groups, and each group was treated with different experimental treatments. There are two independent variables in the experiment. The first one is the materialism (High Materialism versus Low Materialism) [14], which is measured by the questionnaire in the pretest. The second one is the emotion type (Awe versus Peace), which is acquired by using the experimental materials to stimulate the participants' feelings [18]. And the variable was verified by the manipulation checks. 114 bachelor students from School of Business, Sichuan Normal University participated in this study for the credit in one management course. Of the participants, there are 99 females and 15 males and the average age is 19.7 years old.

\subsection{Experimental Materials}

In this study, there were three kinds of experimental materials. The first experimental material is the Materialism Scale, which references to Richins's Material Value Scale (MVS) [5] and Lee and Guo's revised MVS in the Chinese context [25]. This scale includes 13 questions that based on 3 dimensions, respectively, "define success only by property", "acquiring substance as centrality of life", and "pursuit happiness by obtaining property". The second experimental material is the video to evoke emotions, which references to Rudd et al. [18] and van Cappellen and Sarolou's experimental materials [19]. In this study, we asked the experimental group to watch a 3-minute video, which has the content about the natural landscape with grand scenes. According to the Prototype Theory of Awe, these scenes can induce individuals to produce emotion of awe [17]. We also required the control group to watch another 3-minute video, which had the content about some normal natural scenes. And this video was used to produce only neutral emotion like peace. The third experimental material has two parts, one is the scale about life satisfaction and the other one is the scale about products preference. The life satisfaction scale references to the Satisfaction with Life Scale (SWLS) [26], which has 5 questions measured by using the 7-point Likert scale (1 represents extremely unsatisfied, 7 represents extremely satisfied, and 4 represents neutral). The products preference scale references to Rudd et al.'s experiment design [18], which is used to measure individual's preference between materials-based products and experience-based products. We asked the participants to make choice from the 6-pairs of products in the giving conditions. Each question is measured by the 7-point Likert scale ( 1 represents extremely prefer the experience-based product, 7 represents extremely prefer the materials-bases product, and 4 represents neutral). And the giving conditions are described below:

"Now there is a work-study program, you will get paid by doing some office work in school. If you work (half day/one day/10 days) here, the school will reward you with a gift, which is worth (25/50/500 Chinese Yuan). But please note that this gift is only for your personal consumption that it cannot be transferred or sold to others. Which would you prefer in the paired products?”

25 Chinese Yuan group: A movie ticket versus A pen;

25 Chinese Yuan group: A hair salon coupon versus A glass cup;

50 Chinese Yuan group: A buffet coupon versus A T-shirt;

50 Chinese Yuan group: A theme park ticket versus A prepaid cell phone card;

500 Chinese Yuan group: A coupon for a 3-days travel versus A sneaker;

500 Chinese Yuan group: A concert ticket versus A mp4 player.

\subsection{Experiment Procedure}

The first step is to test the individual's materialism in the pretest. 114 participants filled out the questionnaires to make a self-report about their materialism level. According to the score in the self-report, the participants were divided into two groups, one group with high materialism (group $\mathrm{H}$ ) and the other group with low materialism (group $\mathrm{L}$ ). In the second step, we randomly and equally divided the group $\mathrm{H}$ and group $\mathrm{L}$ again into four groups, namely $\mathrm{H}_{\mathrm{A}}, \mathrm{H}_{\mathrm{B}}, \mathrm{L}_{\mathrm{A}}$ and $\mathrm{L}_{\mathrm{B}}$. And we asked the four groups to receive the stimuli from experimental materials. We arranged the $\mathrm{H}_{\mathrm{A}}$ and $\mathrm{L}_{\mathrm{A}}$ groups to watch a 3-minute video (which can induce the emotion of awe) in the lab and arranged the $\mathrm{H}_{\mathrm{B}}$ and $\mathrm{L}_{\mathrm{B}}$ groups to watch another 3-minute video (which can induce the emotion of peace) in the same time in the next-door lab. After that, we asked all the participants to independently fill out the questionnaires about their current emotion, life satisfaction and the products preference. Finally, we used the SPSS 
20 to analyze the experimental results.

\section{Results}

\subsection{Manipulation Checks}

110 valid responses were collected in this experiment, of which 95 were females and 15 were males. According to the pretest, the results of the self-report with MVS scale showed that the average materialism level of the valid samples were $\mathrm{M}_{\text {_Materialism }}=3.61(\mathrm{SD}=0.68)$. Due to the mean score of materialism, there were group $\mathrm{H}(\mathrm{N}=$ $\left.54, \mathrm{M}_{\mathrm{H} \_ \text {Materialism }}=4.16, \mathrm{SD}=0.46\right)$ and group $\mathrm{L}\left(\mathrm{N}=56, \mathrm{M}_{\mathrm{L}_{\_} \text {Materialism }}=3.08, \mathrm{SD}=0.37\right), \mathrm{M}_{\mathrm{H}_{\_} \text {Materialism }}-$ $\mathrm{M}_{\mathrm{L} \_ \text {Materialism }}=1.08(\mathrm{t}=13.64, \mathrm{p}=0.000)$. And the group $\mathrm{H}$ was significant different from the group $\mathrm{L}$ about the materialism.

After watching the videos, the group $A\left(\mathrm{H}_{\mathrm{A}}\right.$ and $\mathrm{L}_{\mathrm{A}}$ together, $\left.\mathrm{N}=60\right)$ experienced the emotion of awe with average score $\mathrm{M}_{\mathrm{A}_{\_} \mathrm{Awe}}=4.97(\mathrm{SD}=1.54)$, experienced the emotion of peace with average score $\mathrm{M}_{\mathrm{A}_{\_} \text {Peace }}=3.15$ $(\mathrm{SD}=1.63)$. And the group $\mathrm{B}\left(\mathrm{H}_{\mathrm{B}}\right.$ and $\mathrm{L}_{\mathrm{B}}$ together, $\left.\mathrm{N}=50\right)$ experienced the emotion of awe with average score $\mathrm{M}_{\mathrm{B}_{-} \text {Awe }}=3.66$ ( $\mathrm{SD}=1.85$ ), experienced the emotion of peace with average score $\mathrm{M}_{\mathrm{B}_{\_} \text {Peace }}=5.26(\mathrm{SD}=1.63)$.

Then we compared the differences of mean score of materialism between the group A and the group $\mathrm{B}$. For the emotion of awe, $\mathrm{M}_{\mathrm{A}_{\_} \text {Awe }}-\mathrm{M}_{\mathrm{B}_{-} \text {Awe }}=1.30667(\mathrm{t}=4.05, \mathrm{p}=0.000)$; and for the emotion of peace, $\mathrm{M}_{\mathrm{A}_{-} \text {Peace }}-$ $\mathrm{M}_{\mathrm{B}_{\text {Peace }}}=-2.11(\mathrm{t}=-6.76, \mathrm{p}=0.000)$. The results indicated that the group A (received stimulus for awe) significantly experienced the emotion of awe and the group B (received stimulus for peace) significantly experienced the emotion of peace. There is no confounding effect. So we use Awe $=1$ to represent the group $A\left(H_{A}\right.$ and $\left.\mathrm{L}_{A}\right)$ and Awe $=0$ to represent the group $B\left(\mathrm{H}_{B}\right.$ and $\left.\mathrm{L}_{B}\right)$ in the following explanation of the results.

\subsection{Life Satisfaction in Different Experimental Conditions}

The results show that the group $\mathrm{H}_{\mathrm{A}}(\mathrm{N}=29)$ has the mean score of life satisfaction with $\mathrm{M}_{\mathrm{HA} \_ \text {satisfaction }}=3.11$ $(\mathrm{SD}=1.16)$; the group $\mathrm{L}_{\mathrm{A}}(\mathrm{N}=31)$ has the mean score of life satisfaction with $\mathrm{M}_{\mathrm{LA} \_ \text {Satisfaction }}=3.49(\mathrm{SD}=0.92)$; the group $\mathrm{H}_{\mathrm{B}}(\mathrm{N}=25)$ has the mean score of life satisfaction with $\mathrm{M}_{\mathrm{HB} \_ \text {Satisfaction }}=2.33(\mathrm{SD}=0.46)$; the group $\mathrm{L}_{\mathrm{B}}$ $(\mathrm{N}=25)$ has the mean score of life satisfaction with $\mathrm{M}_{\mathrm{LB} \_ \text {Satisfaction }}=3.08(\mathrm{SD}=0.83)$ (see Table 1$)$.

In the condition of peace emotion, the participants with low materialism expressed the higher life satisfaction than the participants with high materialism did ( $\mathrm{M}_{\mathrm{HB}_{-} \text {Satisfaction }}<\mathrm{M}_{\mathrm{LB}_{-} \text {Satisfaction }}$ ), and in the condition of awe emotion, the participants with low materialism also expressed the higher life satisfaction than the participants with high materialism did $\left(\mathrm{M}_{\mathrm{HA} \_ \text {Satisfaction }}<\mathrm{M}_{\mathrm{LA} \_ \text {Satisfaction }}\right)$; moreover, the group $\mathrm{H}_{\mathrm{A}}$ and the group $\mathrm{L}_{\mathrm{B}}$ expressed the similar life satisfaction ( $\mathrm{M}_{\mathrm{HA} \_}$Satisfaction $\approx \mathrm{M}_{\mathrm{LB} \_ \text {Satisfaction}}$ ) (see Figure 1 ). So the hypotheses of H1a-H1d in this study are all supported.

\subsection{Products Preference in Different Experimental Conditions}

The results show that the group $\mathrm{H}_{\mathrm{A}}(\mathrm{N}=29)$ has the mean score of products preference with $\mathrm{M}_{\text {HA_Preference }}=$ 25.59 ( $\mathrm{SD}=6.18)$; the group $\mathrm{L}_{\mathrm{A}}(\mathrm{N}=31)$ has the mean score of products preference with $\mathrm{M}_{\mathrm{LA} \_ \text {Preference }}=23.42$ ( $\mathrm{SD}=5.69)$; the group $\mathrm{H}_{\mathrm{B}}(\mathrm{N}=25)$ has the mean score of products preference with $\mathrm{M}_{\mathrm{HB} \_ \text {Preference }}=33.40$ ( $\mathrm{SD}=$ 3.12); the group $L_{B}(N=25)$ has the mean score of products preference with $M_{L_{-} \_ \text {Preference }}=23.08(S D=6.92)$ (see Table 2).

In this study, we defined that if the sum of the score for the 6-pairs choices is less than 24 (which represents the sum of the score for neutral decisions), it means the participant prefers to the experience-based products over

Table 1. The affect of the materialism and emotion type on life satisfaction.

\begin{tabular}{ccccc}
\hline Materialism & Emotion type & M & SD & N \\
High materialism & Awe & M $_{\text {HA_Satisfaction }}=3.11$ & 29 \\
High materialism & Peace & M $_{\text {HB_Satisfaction }}=2.33$ & 0.46 & 25 \\
Low materialism & Awe & M $_{\text {LA_Satisfaction }}=3.49$ & 0.92 & 0.83 \\
Low materialism & Peace & M $_{\text {LB_Satisfaction }}=3.08$ & 25 \\
\hline
\end{tabular}




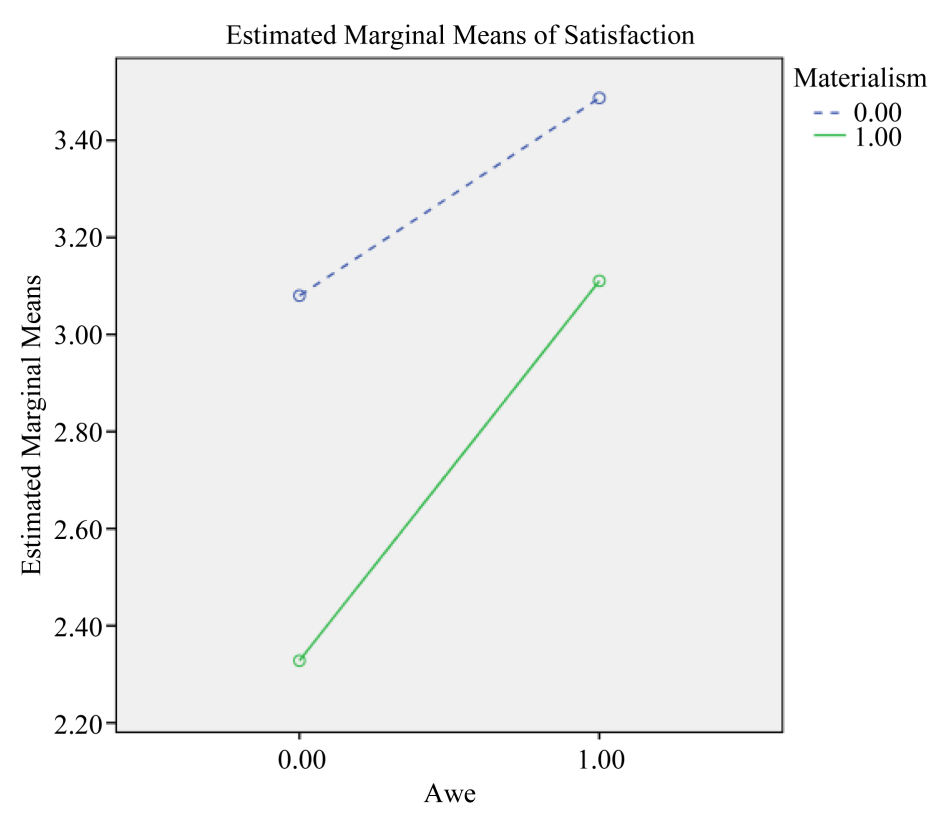

Figure 1. The affect of the materialism and awe on life satisfaction.

Table 2. The affect of the materialism and emotion type on products preference.

\begin{tabular}{ccccc}
\hline Materialism & Emotion type & M & SD & N \\
\hline High materialism & Awe & $\mathbf{M}_{\text {HA_Preference }}=25.59$ & 6.18 & 29 \\
High materialism & Peace & $\mathrm{M}_{\text {HB_Preference }}=33.40$ & 3.12 & 25 \\
Low materialism & Awe & $\mathrm{M}_{\text {LA_Preference }}=23.42$ & 5.69 & 31 \\
Low materialism & Peace & $\mathrm{M}_{\text {LB_Preference }}=23.08$ & 6.92 & 25 \\
\hline
\end{tabular}

the materials-based products, and vice versa. In the condition of peace emotion, the participants with low materialism preferred to experience-based products over the participants with high materialism did ( $\mathrm{M}_{\mathrm{HB} \_ \text {Preference }}>$

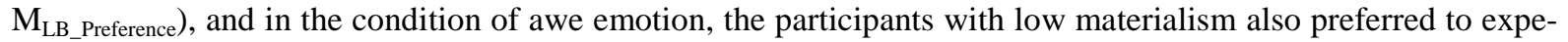
rience-based products over the participants with high materialism did $\left(\mathrm{M}_{\mathrm{HA} \_ \text {Preference }}>\mathrm{M}_{\mathrm{LA} \_ \text {Preference }}\right)$; moreover, the group $\mathrm{H}_{\mathrm{A}}$ and the group $\mathrm{L}_{\mathrm{B}}$ showed the similar products preference $\left(\mathrm{M}_{\mathrm{HA} \_ \text {Preference }} \approx \mathrm{M}_{\mathrm{LB}}\right.$ Preference) (see Figure 2). So the hypotheses of H2a-H2d in this study are all supported as well.

\subsection{Discussion}

According to the results, this study found out that the individual with low materialism would feel higher life satisfaction than the individual with high materialism did $\left(\mathrm{M}_{\mathrm{LA} \text { _Satisfaction }}>\mathrm{M}_{\mathrm{LB} \_ \text {Satisfaction }} \approx \mathrm{M}_{\mathrm{HA} \text { _Satisfaction }}>\right.$ $\left.\mathrm{M}_{\mathrm{HB} \_ \text {Satisfaction }}\right)$. This result is in agreement with findings in previous studies that people will decline their life satisfaction by the effects of materialism [12]. In addition to that, once the individual gets the experience of awe emotion, the individual will be able to significantly improve their life satisfaction $\left(\mathrm{M}_{\mathrm{HA} \_ \text {Satisfaction }}=3.11\right.$, [2.79, 3.44] $)>\left(\mathrm{M}_{\mathrm{HB} \text { _Satisfaction }}=2.33\right.$, [1.97, 2.68]). This result fully proved that the emotion of awe, as a topical kind of positive emotions, can be beneficial for the promotion of people's life satisfaction [18]. Moreover, the result further notes that the emotion of awe can offset against the bad impact that the materialism reduces people's life satisfaction. In other words, if people experience the emotion of awe in their work, life and entertainment environment, they would keep a positive attitude towards life, no matter how high of the materialism level they have.

This study also found that the materialism can influence people's products preference that people with low materialism would normally prefer to experience-based products over materials-based products $\left(\mathrm{M}_{\mathrm{LA} \_ \text {Preference }} \approx\right.$ $\mathrm{M}_{\mathrm{LB} \_ \text {Preference }}<\mathrm{M}_{\mathrm{HA} \_ \text {Preference }}<\mathrm{M}_{\mathrm{HB} \_ \text {Preference }}$ ). In previous studies, Richins and Dawson indicated that the materialists would more like to acquire material merchandises [5]. Howell et al. also found that there was a negative 


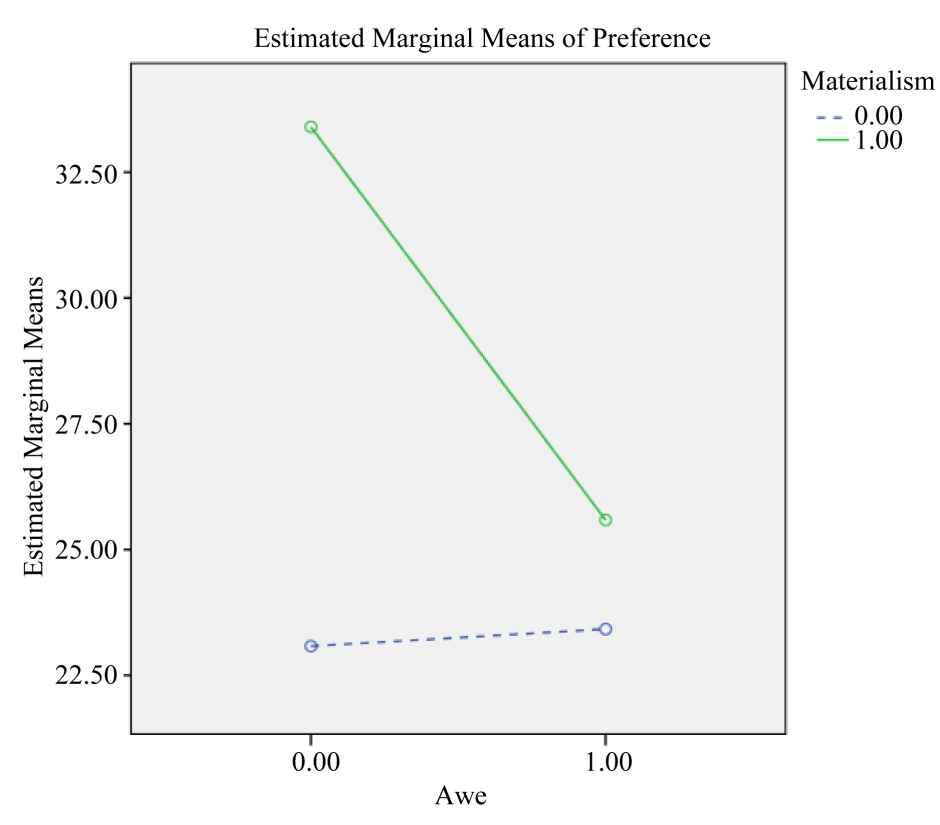

Figure 2. The affect of the materialism and awe on products preference.

relationship between people's materialism level and their preference for the experience-based products [16], namely, people with high materialism are less likely to obtain the experience-based products. More importantly, the result of this study showed that the emotion of awe can significantly influence people's products preference. That is to say, when the individual experiences the emotion of awe, the individual will decline the preference for the materials-based products $\left(\mathrm{M}_{\text {HA_Preference }}=25.59,[23.49,27.68]\right)<\left(\mathrm{M}_{\text {HB_Preference }}=33.40,[31.15,35.65]\right)$. Therefore, the emotion of awe can offset the bad impact of materialism on people that only worship money and commodities. The emotion of awe can also awaken people from the material world in secular life, and promote people for the pursuit of the spiritual world.

\section{Conclusion}

The results of this study support the previous theories that the materialism can reduce people's life satisfaction and affect people's preferences for materials-based products. Additionally, this study also finds that the emption of awe cannot only improve people's life satisfaction, but also promote people to prefer to the experience-based products. Moreover, this study indicates that the emotions of awe can offset against the negative effects on people from the materialism, and can help people to raise a positive attitude to their life and also to pursue the spiritual world. And there are some further research suggestions that in some specific context such as tourism environment, people may experience the emotion of awe from the stimulus of grand scenes or sacred atmosphere and then they may increase their travel satisfaction and produce some positive behaviors as well.

\section{Funding}

This study was funded by MOE (Ministry of Education in China) Project of Humanities and Social Sciences (Project No.15XJC790008).

\section{References}

[1] Tao, D.F. (2012) Distortion of Secular and Contemporary Chinese Popular Culture. Exploration and Free Views, 5, 3-5.

[2] Myers, D.G. and Twenge, J.M. (2013) Social Psychology. McGraw-Hill, New York.

[3] Fredrickson, B.L. (2001) The Role of Positive Emotions in Positive Psychology: The Broaden-and-Build Theory of Positive Emotions. American Psychologist, 56, 218-226. http://dx.doi.org/10.1037/0003-066X.56.3.218

[4] Shiota, M.N., Campos, B. and Keltner, D. (2003) The Faces of Positive Emotion. Annals of the New York Academy of Sciences, 1000, 296-299. http://dx.doi.org/10.1196/annals.1280.029 
[5] Richins, M.L. and Dawson, S. (1992) A Consumer Values Orientation for Materialism and Its Measurement: Scale Development and Validation. Journal of Consumer Research, 19, 303-316. http://dx.doi.org/10.1086/209304

[6] Sirgy, M.J. (1998) Materialism and Quality of Life. Social Indicators Research, 43, 227-260. http://dx.doi.org/10.1023/A:1006820429653

[7] Chan, K. and Prendergast, G. (2007) Materialism and Social Comparison among Adolescents. Social Behavior and Personality: An International Journal, 35, 213-228. http://dx.doi.org/10.2224/sbp.2007.35.2.213

[8] Roberts, J.A. and Clement, A. (2007) Materialism and Satisfaction with Over-All Quality of Life and Eight Life Domains. Social Indicators Research, 82, 79-92. http://dx.doi.org/10.1007/s11205-006-9015-0

[9] Pieters, R. (2013) Bidirectional Dynamics of Materialism and Loneliness: Not Just a Vicious Cycle. Journal of Consumer Research, 40, 615-631. http://dx.doi.org/10.1086/671564

[10] Mueller, A., Mitchell, J.E., Peterson, L.A., Faber, R.J., Steffen, K.J., Crosby, R.D. and Claes, L. (2011) Depression, Materialism, and Excessive Internet Use in Relation to Compulsive Buying. Comprehensive Psychiatry, 52, 420-424. http://dx.doi.org/10.1016/j.comppsych.2010.09.001

[11] Christopher, A.N., Drummond, K., Jones, J.R., Marek, P. and Therriault, K.M. (2006) Beliefs about One’s Own Death, Personal Insecurity, and Materialism. Personality and Individual Differences, 40, 441-451. http://dx.doi.org/10.1016/j.paid.2005.09.017

[12] Christopher, A.N., Saliba, L. and Deadmarsh, E.J. (2009) Materialism and Well-Being: The Mediating Effect of Locus of Control. Personality and Individual Differences, 46, 682-686. http://dx.doi.org/10.1016/j.paid.2009.01.003

[13] Dittmar, H. (2005) Compulsive Buying-A Growing Concern? An Examination of Gender, Age, and Endorsement of Materialistic Values as Predictors. British Journal of Psychology, 96, 467-491. http://dx.doi.org/10.1348/000712605X53533

[14] Nicolao, L., Irwin, J.R. and Goodman, J.K. (2009) Happiness for Sale: Do Experiential Purchases Make Consumers Happier than Material Purchases? Journal of Consumer Research, 36, 188-198. http://dx.doi.org/10.1086/597049

[15] Richins, M.L. (2004) The Material Values Scale: Measurement Properties and Development of a Short Form. Journal of Consumer Research, 31, 209-219. http://dx.doi.org/10.1086/383436

[16] Howell, R.T., Pchelin, P. and Iyer, R. (2012) The Preference for Experiences over Possessions: Measurement and Construct Validation of the Experiential Buying Tendency Scale. The Journal of Positive Psychology, 7, 57-71. http://dx.doi.org/10.1080/17439760.2011.626791

[17] Keltner, D. and Haidt, J. (2003) Approaching Awe, a Moral, Spiritual, and Aesthetic Emotion. Cognition \& Emotion, 17, 297-314. http://dx.doi.org/10.1080/02699930302297

[18] Rudd, M., Vohs, K.D. and Aaker, J. (2012) Awe Expands People’s Perception of Time, Alters Decision Making, and Enhances Well-Being. Psychological Science, 23, 1130-1136. http://dx.doi.org/10.1177/0956797612438731

[19] Van Cappellen, P. and Saroglou, V. (2012) Awe Activates Religious and Spiritual Feelings and Behavioral Intentions. Psychology of Religion and Spirituality, 4, 223-236. http://dx.doi.org/10.1037/a0025986

[20] Kasser, T. and Ryan, R.M. (1996) Further Examining the American Dream: Differential Correlates of Intrinsic and Extrinsic Goals. Personality and Social Psychology Bulletin, 22, 280-287. http://dx.doi.org/10.1177/0146167296223006

[21] Solberg, E.G., Diener, E. and Robinson, M.D. (2004) Why Are Materialists Less Satisfied? In: Kasser, T. and Kanner, A., Eds., Psychology and Consumer Culture: The Struggle for a Good Life in a Materialistic World, American Psychological Association, Washington DC, 29-48.

[22] Richins, M.L. (2013) When Wanting Is Better than Having: Materialism, Transformation Expectations, and ProductEvoked Emotions in the Purchase Process. Journal of Consumer Research, 40, 1-18. http://dx.doi.org/10.1086/669256

[23] Tsang, J.-A., Carpenter, T.P., Roberts, J.A., Frisch, M.B. and Carlisle, R.D. (2014) Why Are Materialists Less Happy? The Role of Gratitude and Need Satisfaction in the Relationship between Materialism and Life Satisfaction. Personality and Individual Differences, 64, 62-66. http://dx.doi.org/10.1016/j.paid.2014.02.009

[24] Curtin, S. (2005) Nature, Wild Animals and Tourism: An Experiential View. Journal of Ecotourism, 4, 1-15. http://dx.doi.org/10.1080/14724040508668434

[25] Lee, J. and Guo, Y.Y. (2008) Materialism and the Relevant Studies. Advances in Psychological Science, 16, 637-643.

[26] Diener, E., Emmons, R., Larsen, R. and Griffin, S. (1985) The Satisfaction with Life Scale. Journal of Personality Assessment, 49, 71-75. http://dx.doi.org/10.1207/s15327752jpa4901 13 